\title{
Learning Styles of Students of Postgraduate Studies in Engineering
}

\author{
Tulsi PK' ${ }^{1}$; Poonia MP ${ }^{2}$ and Anu Priya ${ }^{3}$ \\ ${ }^{1}$ Education and Educational Management Department, NITTTTR \\ ${ }^{2}$ Director, NITTTTR, Chandigarh \\ ${ }^{3}$ Anu Priya, ME Student, NITTTR \\ ${ }^{1}$ pk_tulsi@yahoo.com \\ 2 mppoonia11@gmail.com \\ 3anupriya.cse@nitttrchd.ac.in
}

\begin{abstract}
The study aimed at determining the learning styles of students pursuing master's degree programmes in engineering. Index of Learning Style was administered to 175 students. The findings reveal that there exist differences in learning styles of students pursuing master's degree in computer science and engineering, civil engineering, electrical engineering, electronics and communication engineering and mechanical engineering. Majority of the students of various branches except of mechanical engineering prefer active, sensing, visual and sequential learning styles but very few of them have strong preference for a particular learning style.
\end{abstract}

Keywords: Learning styles Engineering students

\section{Introduction}

Heterogeneity among the learners have increased manifold during the last fifteen years with the massive expansion of technical education in the country. Teachers are facing numerous challenges including how to cater to the needs of diverse groups of learners existing within the classroom. Though differences exist with respect to previous attainments, age, gender, rural-urban, intelligence, aptitude, learning styles, interest, personality etc., but one of these variables that affect the performance of students is their learning style. Numerous studies in the area (Bahar, 2009;

Cutolo and Rochford, 2007; Dzakiria, Razak and Mohammed, 2004; Heiman, 2006; Johnson and Johnson, 2006; Saroj Kumari, 2013 and Thomas, Ratcliffe, Woodbury and Jarman, 2002) lend support to this argument. The best way of conceiving individual differences is through understanding of learning styles (Hall, 2005). In addition, it has been recognized that if teaching style of teachers and learning styles of students match or instructional strategies match learning style of students, learning can be maximized (Dowdall, 1991; Dzakiria, Razak and Mohammed, 2004; Fazarro, Pannkuk, Pavelock and Hubbard, 2009; Felder and Silverman, 2002; Holliday \& Said, 2008; Namie, Siraj, Abuzaid and Shagholi, 2010; Spoon \& Schell, 1998 andZippert, 1985).
Dean R\&D, NITTTR, Sector 26, Chandigarh-160019

${ }^{1}$ pk_tulsi@yahoo.com 


\section{Learning Styles: Concept \& Classification}

Learning style has been defined as the way in which learner begins to concentrate, process andretain new and difficult information (Dunn\& Dunn, 1970). Initially, twenty oneelements were identified for understanding the situation in which learning takes place but were modifiedlater into five elements namely environmental, emotional, sociological, physiological and psychological. These elements interact differently for different individuals.

Cross (1976) defined learning styles as the characteristic ways that individuals collect, organize and transfer information into useful knowledge. Gregore and Ward (1977) gave operational definition of the term as characteristic set of behaviours of people which describes how their minds relate to the world and therefore, how they learn. O'keefe and Nadel (1978), on the basis of various definitions, concluded that learning styles are cognitive, affective and physiological traits that serve as relatively stable indicators of how learners perceive, interact with, and respond to that learning environment. Keefe and Languis (1983) also defined learning style in a similar way.

Learning style, according to Kolb (1984), is the preferred way that the individual deals with given information and how she/he constructs meaning out of stimuli. He classified learning styles into convergers, divergers, assimilators and accommodators. Convergers learn best through active experimentation and abstract conceptualization. They like to workby themselves, solve problems and find practical solution. Divergers are characterized by concrete experience and reflective observation. They view things from multiple perspectives, are open-minded and prefer to work with people. Assimilator learning style ischaracterized by abstract conceptualization and reflective observation. Assimilators prefer to think than to act and are good at creating theoretical models. Accomodators learn by actively engaging with the world and actually doing things. They have strong preference for doing, are risk-takers and tend to solve problems based on their own information.Kolb (2005) however stated that there is no JEב such thing as a fixed learning style; rather learning occurs on a continuum ranging from concrete to abstract or from reflective observation to active experimentation.

Honey and Mumford (2000) replaced the term reflectors for divergers, theorists for assimilators, pragmatist for convergers and activists for accommodators. Reflectors prefer to learn from activities that allow them to watch, think and review what has happened. Theorists prefer to think problems through step-by-step manner. Pragmatistsapply new learning to actual practice to see if they work. Activists prefer challenges of new experiences, involvement with others, assimilation and role- playing.

Felder and Silverman (1988) classified learning style into four dimensions namely: active-reflective, sensing-intuitive, visual-verbal and sequential and global.. Felder (2000) identified the major characteristics of different learning styles as detailed below:

Active-Reflective (ACT-REF)

- Active learners tend to retain and understand information best by doing something active with it-discussing or applying it or explaining it to others. Reflective learners prefer to think about it quietly first.

- Active learners tend to like group work more than reflective learners, who prefer working alone.

Sensing-Intuitive(SEN-INT)

- Sensing learners tend to like learning facts, intuitive learners often prefer discovering possibilities and relationships.

- Sensors often like solving problems by wellestablished methods and dislike complications and surprises; intuitors resent being tested on material that has not been explicitly covered in class.

- Sensors tend to be patient with details and good at memorizing facts and doing hands-on(laboratory) work; intuitors may be better at grasping new concepts and are often more comfortable than sensors with abstractions and mathematical formulations. 
- Sensors tend to be more practical and careful thinkers; intuitors tend to work faster and to be more innovative than sensors.

- Sensors donot like courses that have no apparent connection to the real world; intuitors do not like 'plug-and-chug' courses that involve a lot of memorization and routine calculations.

Visual-Verbal (VIS-VBL)

- Visual learners remember best what they seepictures, diagrams, flow charts, time lines, films and demonstrations. Verbal learnersget moreout of words-written and spoken .

- Everyone learns more when information is presented both visually and verbally.

\section{Sequential-Global (SEQ-GLO)}

- Sequential learners tend to gain understanding in linear steps, with each step following logically from the previous one. Global learners tend to learn in large jumps, absorbing material almost randomly without seeing connections, and then suddenly getting it.

Sadler-Smith's (1996) onion model tries to clarify the differences among the three terms i.e. learning styles, learning preferences and learning strategies. According to him learning styles are relatively more stable than the learning preferences and strategies that are influenced more by the environment.

The present study was undertaken primarily to study the differences in the learning styles of students pursuing master's degree in different branches of engineering and suggest strategies for meeting diverse needs of students with different learning styles.

\section{Sample}

Sample for the study comprised of 175 students pursuing their master's degree programme in various branches of engineering at National Institute of Technical Teachers Training \& Research, Chandigarh. The distribution of sample across five branches of engineering is given in Table1.

Table 1: Sample of the study

\begin{tabular}{|c|l|l|}
\hline S.No & Branch & Number of Students \\
\hline 1. & $\begin{array}{l}\text { Computer Science \& Engineering } \\
(\mathrm{CSE})\end{array}$ & 32 \\
\hline 2. & Civil engineering (CE) & 30 \\
\hline 3. & Electrical engineering (EE) & 37 \\
\hline 4. & $\begin{array}{l}\text { Electronics \& Communication } \\
\text { Engineering (ECE) }\end{array}$ & 31 \\
\hline 5. & Mechanical Engineering (ME) & 45 \\
\hline
\end{tabular}

\section{Tool Used}

Index of Learning Styles (Felder and Soloman,1994) was used to determine the learning styles of students. The inventory measures four learning styles- Active-Reflective, Sensors-Intuitive, Visual-Verbal and Sequential-Global. The inventory consists of 44 statements. Each statement has two response alternatives. The respondent is required to tick mark the one which he/she thinks is more applicable. If the score of an individual falls between 1-3, the individual has a balanced learning style, if it falls between 5-7, the individual has moderate preference for one of the dimensions of learning style and if the score of an individual falls between 9-11, the individual has a strong preference for a particular dimension of learning style. The ILS is widely used by the researchers due to its psychometric properties.

\section{Data Analysis and Results}

The data was subjected to calculation of frequencies and percentages. Table 2 shows the percentage of students having preference for various learning styles.

Table2: Percentage of Students having Preference for Various Learning styles

\begin{tabular}{|l|l|l|l|l|l|l|l|l|l|}
\hline $\begin{array}{l}\text { S.N } \\
\text { o }\end{array}$ & $\begin{array}{l}\text { Bran } \\
\text { ch }\end{array}$ & $\begin{array}{l}\text { AC } \\
\text { T }\end{array}$ & $\begin{array}{l}\text { RE } \\
\text { F }\end{array}$ & $\begin{array}{l}\text { SE } \\
\mathbf{N}\end{array}$ & $\begin{array}{l}\text { IN } \\
\text { T }\end{array}$ & $\begin{array}{l}\text { VI } \\
\text { S }\end{array}$ & $\begin{array}{l}\text { VR } \\
\text { B }\end{array}$ & $\begin{array}{l}\text { SE } \\
\mathbf{Q}\end{array}$ & $\begin{array}{l}\text { GL } \\
\mathbf{O}\end{array}$ \\
\hline 1 & CSE & 69 & 31 & 69 & 31 & 91 & 9 & 75 & 25 \\
\hline 2 & CE & 50 & 50 & 70 & 30 & 87 & 13 & 70 & 30 \\
\hline 3 & EE & 62 & 38 & 57 & 43 & 95 & 5 & 54 & 46 \\
\hline 4 & ECE & 55 & 45 & 65 & 35 & 90 & 10 & 65 & 35 \\
\hline 5 & ME & 49 & 51 & 60 & 40 & 96 & 4 & 67 & 33 \\
\hline
\end{tabular}


It is evident from Table 2 that majority of the students of CSE, EE and ECE have preference for active, sensing, visual and sequential learning style. Equal percentage of students of civil engineering has preference for active and reflective learning styles respectively. ME students also prefer all these styles except active learning style. Majority of ME students have preference for reflective learning style. Majority of the students pursuing masters in various branches of engineering except mechanical engineering thus tend to learn by discussing, applying or explaining the information to others. Mechanical engineering students, however, prefer learning by reflecting on the information and prefer independent learning. Majority of the students of all branches like facts, details and solve problems by wellestablished methods. They prefer learning through pictures, diagrams, flowcharts, videos etc.

Fig. 1 to 5 shows the percentage of students of the five branches of engineeringwith slight, moderate and strong preferencesfor different learning styles.

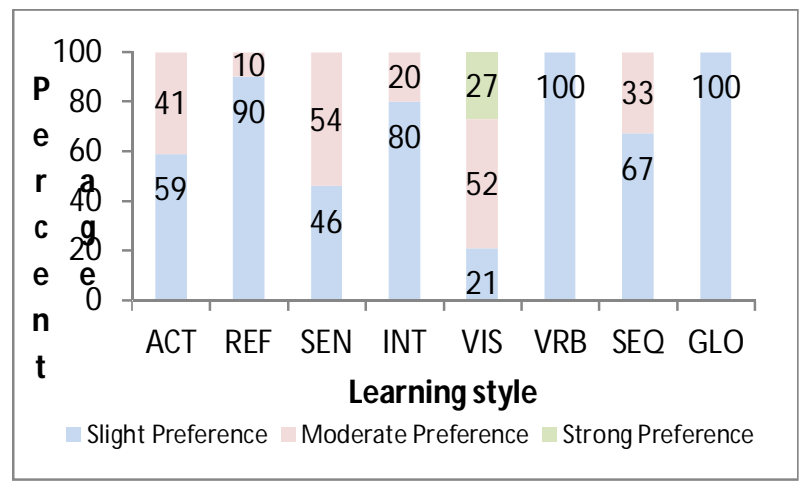

Fig. 1: Learning styles of Computer Science and Engineering students

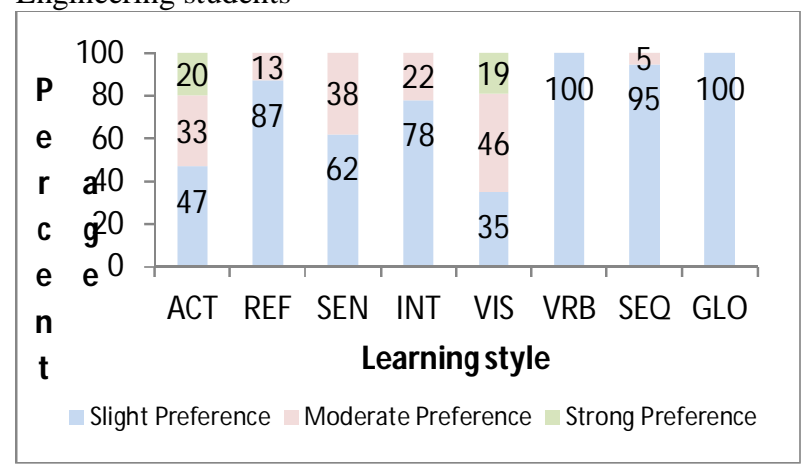

Fig.2: Learning styles of Civil Engineering students

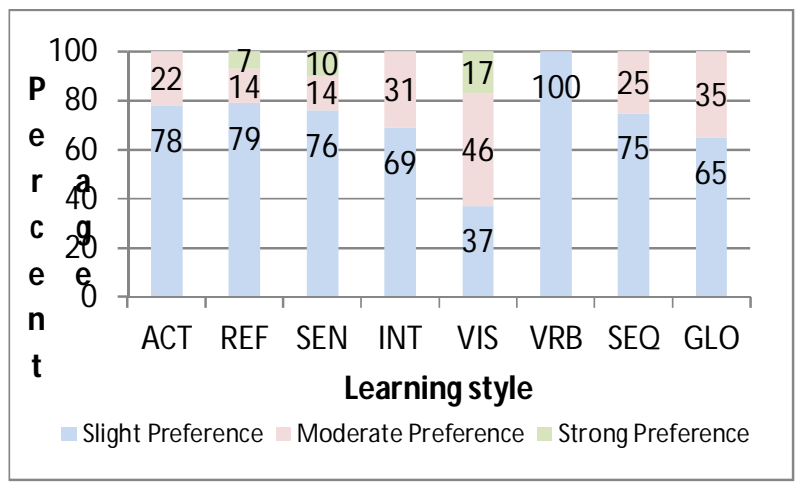

Fig3: Learning styles of Electrical Engineering students

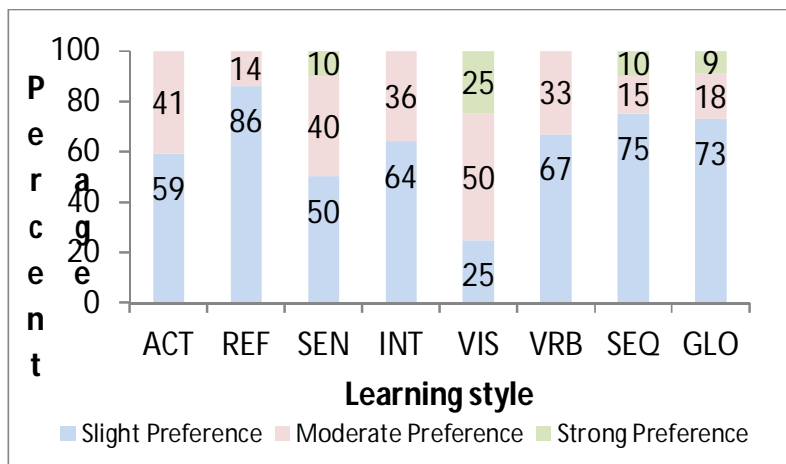

Fig4: Learning styles of Electronics \& Communication Engineering students

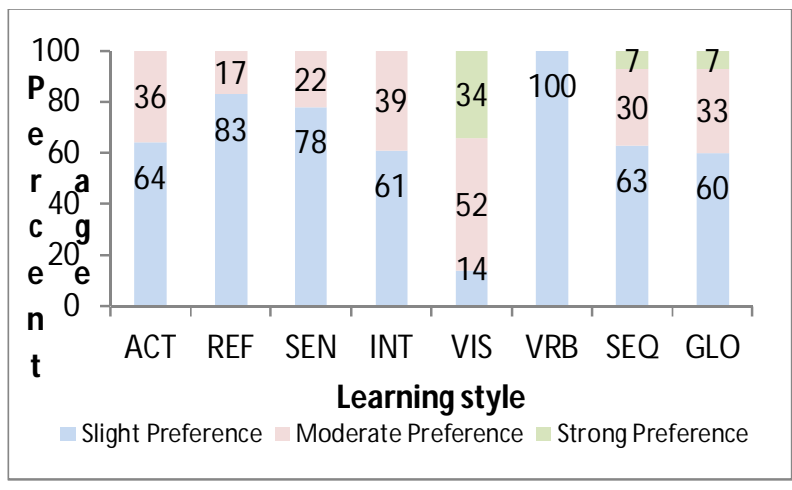

Fig. 5: Learning styles of Mechanical Engineering students

From the figures above, it can be concluded that very few students of various branches show strong preference for one or the other learning style except for visual learning style in which case, students ranging between 17 and $37 \%$ show strong preference. $20 \%$ of the students from CE show strong preference for active learning style. $10 \%$ of $\mathrm{EE}$ students have strong preference for sensing style of learning. $10 \%$ and $7 \%$ of students of ECE and ME indicate strong preference for sequential learning styles. Other 
students of various branches show either slight preference or moderate preference for one or the other learning style. The percentage of students having moderate preference for one or the other learning style ranged from 10 to $54 \%$.

The findings reveal that there exist differences in the learning styles of students pursuing various branches of engineering. Earlier studies (Bisht, 2011; Johnson and Johnson, 2006; SarojKumari, 2013; and Vermont, 1996) lend support to the findings of the present study. Information provided to open ended questions revealed that teachers primarily use lecture method with use of power point slides in the classrooms. Some of the teachers use seminar strategy and some use case studies and video films. However, their number is quite meager Students were of the opinion that when the subject was related to world of work or daily life, it made sense to them and they are of the opinion that greater emphasis has to be on the practical aspects rather than theory.

\section{Implications for Teachers}

On the basis of the findings, it can be said that no one teaching strategy can be preferred over others. Teachers need to use an appropriate mix of different instructional strategies to cater to the needs of students with varying learning styles. Some of the proposed strategies include the following:

- Verbal explanation should be accompanied by visual representation to facilitate learning among postgraduate students. Engineering subjects provide ample scope for inclusion of visuals in the teaching learning. Verbal explanations need to be supported by concept maps, diagrams, charts, pictures, videos, animation and simulations.

- As most of the students prefer sensing style, where ever possible, examples from real world should be given to support concepts, theories, procedures and principles to cater to the needs of sensors. Applications in day to day life and in the world of work need to be highlighted.
- Teachers need to bring in the element of innovation and creativity in their teaching and encourage students to use their imagination and build associations. Strategies like brainstorming attribute listing, brain writing, writing of analogies and metaphors etc. can help intuitors.

- To maximize learning of students with active learning style, teachers need to allow students to discuss concepts, theories and techniques in groups and tryout things. Strategies like think-pair-share, buzz groups, extended buzz groups, pyramiding, group discussion, collaborative problem- solving, case studies, debates, project work or problem-based learning etc. can be used to encourage active learning.

- For reflective learners, provide time to students to reflect back and answer questions or write applications of learnt concepts, principles and procedures. Ask the students to write summaries of what they have learnt or write how theyhave arrived at certain solution to the problem.

- In order to maximize learning among sequential learners, step- by- step approach needs to be followed in teaching but overview of topics or advance organizers can be given or used to help global learners.

\section{Conclusions}

From the findings stated above, it can be concluded that as there exist differences in the learning styles of students pursuing master's degree in engineering and a few students with strong preference for one ofthe learning styles except visual learning style, teachers need to use a variety of instructional strategies to cater to the diverse needs of the learners.

\section{References}

Bahar, Mehmet (2009), The relationships between pupils' learning styles and their performance in mini science projects, Kuram ve Uygulamada Egitim 
Bilimleri/Educational Sciences: Theory \& Practice, 9:1, 31-49.

Bisht, N.S.A. (2011). The effect of learning styles and personality types on the academic achievement of diploma students of electrical engineering in the state of Uttrakhand. Unpublished thesis, submitted to Panjab University.

Cross, K. (1976), Accent on Learning, San Francisco: Jossey-Bass.

Cutolo, A \& Rochford Regina A. (2007). An Analysis of freshmen learning styles and their relationship to academic achievement. College Quarterly, $10: 2$ 1-17.

Dowdall, R.J. (1991), Learning style and the distant learner, Consortium project extending the concept and practice of classroom based research report, ERIC Document Reproduction Service No. ED 348117.

Dunn, R. (2000), Learning styles, research, and practice, National Forum of Applied Educational Research Journal, 13:1, 3-22.

Dzakiria, H., Razak, A. A., \& Mohamed, A. H. (2004). Improving distance courses: Understanding teacher trainees and their learning styles for the design of teacher training courses and materials at a distance. Turkish Online Journal of Distance Education, 5(1).

Fazarro, Dominick E., Pannkuk, Tim, Pavelock, Dwayne, and Hubbard, Darcy (2009), The effectiveness of instructional methods based on learning style preferences of agricultural students: A research tool for continuous improvement for faculty in career and technical education (CTE) programs, Journal of Industrial Teacher Education, 45:3, 84-104.

Felder, R.M. \& Silverman, L.K. (1988), Learning and teaching styles in engineering education, Engineering Education,78:7, 674-681.

Felder, R.M. \&Soloman, B. A. (!994) Index of Learning Style. North Carolina University.

Felder, R.M. and Silverman L.K. (2002), Learning and teaching styles in engineering education, Engineering Education, 78:7,.674-681.

Gregore, A.F.\& Ward, H.B. (1977), A new definition for individual: implications for learning and teaching, NASSP Bulletin, 401:6,.20-23.

Hall, J. (2005), Neuroscience and education: A review of the contribution of brain science to teaching and learning, Scottish Council for Research in Education.

Heiman, Tali (2006), Assessing Learning styles among students with and without learning disabilities at a Distance-Learning University, Learning Disability Quarterly, 29, 55-63.

Holliday, Tacy L. \& Said, Sukhaynah H (2008) Psychophysiological measures of learning comfort: study groups' learning styles and pulse changes, Learning Styles and Pulse, TLAR, 13:1, 7-16.

Honey, P. \& Mumford, A. (2000), The learning styles helper's guide, Maidenhead: Peter Honey Publications Ltd. Johnson, Genevieve Marie \& Johnson, Julia Ann (2006), Learning style and preference for online learning support: Individual quizzes versus study groups, ED-MEDIA, 1861-1868.

Keefe, J. W. \& Languis, M.L. (1983). Operational Definitions. Paper presented to the NASSP Learning Styles Task Force, Reston, Virginia.
Kolb, D.A. (1984), Experiential Learning: Experience as the source of learning and development, Englewood Cliffs: Prentice Hall.

Kolb, A.Y., \& Kolb, D.A. (2005), Learning styles and learning spaces: Enhancing learning in higher education, Academy of Management Learning and Education, 4:2, 193-212.

Naimie, Zahra, Siraj, Saedah\& Abuzaid, Rana Ahmed, Shagholi, Reihaneh (2010), Hypothesized learners' technology preferences based on learning style dimensions, TOJET: The Turkish Online Journal of Eduational Technology, 9:4, 83-93.

O' Keefe, J. and L. Nadel (1978), The Hippocampus as a cognitive map, Clarendon Press, Oxford, UK.

Sadler-Smith, E. (1996), Learning Styles: A holistic approach, Journal of European Industrial Training, 20:7, 29-36.

SarojKumari (2013). Personality, learning styles and performance of students in various disciplines of engineering in Lucknow. Unpublished thesis submitted to Panjab University.

Spoon, J.C. and Schell, J.W. (1998), Aligning student learning styles with instructor teaching styles, Journal of Industrial Teacher Education, 35:2, 41-56.

Thomas, Lynda; Ratcliffe, Mark; Woodbury, John \& Jarman, Emma (2002), Learning styles and performance in the introductory programming sequence.

Vermunt, J.D. (1996), Metacognitive, cognitive and affective aspects of learning styles and strategies: A phenomenographic analysis, Higher Education, Netherlands: Kluwer Academic Publishers, 31,25-50.

Zippert,C. P. (1985). The effectiveness of adjusting teaching strategies to assessed learning stvles of adult students. Doctoral dissertation. University of Alabama 